\title{
Correction to: Feature extraction and machine learning solutions for detecting motion vector data embedding in HEVC videos
}

\section{Tamer Shanableh ${ }^{1}$}

Published online: 15 June 2021

C) Springer Science+Business Media, LLC, part of Springer Nature 2021

\section{Correction to: Multimedia Tools and Applications (2020)} https://doi.org/10.1007/s11042-020-09826-1

In the original publication of this article, Eq. 1 contains duplicate data. The original article has been corrected.

Publisher's note Springer Nature remains neutral with regard to jurisdictional claims in published maps and institutional affiliations.

The online version of the original article can be found at https://oi.org/10.1007/s11042-020-09826-1

Tamer Shanableh tshanableh@aus.edu

1 Department of Computer Science and Engineering, American University of Sharjah, Sharjah, United Arab Emirates 